\title{
Finding determinants of audit delay by pooled OLS regression analysis
}

\author{
Tina Vuko ${ }^{1}$ and Marko Čular ${ }^{2, *}$ \\ ${ }^{1}$ Accounting department, Faculty of Economics, University of Split \\ Cvite Fiskovica 5, HR-21000 Split, Croatia \\ E-mail:〈tina.vuko@efst.hr〉 \\ ${ }^{2}$ Accounting department, Faculty of Economics, University of Split \\ Cvite Fiskovica 5, HR-21000 Split, Croatia \\ E-mail: 〈marko.cular@efst.hr〉
}

\begin{abstract}
The aim of this paper is to investigate determinants of audit delay. Audit delay is measured as the length of time (i.e. the number of calendar days) from the fiscal year-end to the audit report date. It is important to understand factors that influence audit delay since it directly affects the timeliness of financial reporting. The research is conducted on a sample of Croatian listed companies, covering the period of four years (from 2008 to 2011). We use pooled OLS regression analysis, modelling audit delay as a function of the following explanatory variables: audit firm type, audit opinion, profitability, leverage, inventory and receivables to total assets, absolute value of total accruals, company size and audit committee existence. Our results indicate that audit committee existence, profitability and leverage are statistically significant determinants of audit delay in Croatia.
\end{abstract}

Key words: audit delay, timeliness of corporate reporting, listed companies

Received: October 25, 2013; accepted: March 5, 2014; available online: March 20, 2014

\section{Introduction}

Timeliness is an important characteristic of accounting information, since timely reporting provides more decision-useful information. Timeliness enhances both relevant and faithfully represented information, and is therefore an enhancing qualitative characteristic [13]. Audit delay can affect the timeliness of accounting information releases [1]. Moreover, it is considered to be the single most important determinant of the timeliness of the earnings announcement [12]. The audit report date is the date on which the auditor has obtained sufficient appropriate audit evidence to support the opinion, including evidence that all financial statements have been prepared and that the management have asserted that they have taken responsibility for those financial statements.

The timeliness of financial reporting is especially important for well functioning of capital markets as it reduces information asymmetry and enhances decisionusefulness of information. Croatian Capital Market Act, Article 403 [25] requires

${ }^{*}$ Corresponding author. 
listed companies to make their annual financial report public (including audited financial statements and audit report) four months at the latest after the end of the financial year. Even though regulatory bodies impose certain requirements regarding the financial reporting timeliness, considerable discretion still remains within the regulatory framework. Timely reporting in emerging markets is of particular importance since in these markets information is relatively limited and has a longer time lag [21]. Also, according to the McGee and Yuan [19], there is evidence that companies in transition economies issue their financial statements much later than companies in more developed market economies. In these countries, different factors might be important in explaining the audit lag with respect to annual financial statements. Therefore, this study extends the previous literature on the timeliness of financial reporting by analysing potential determinants of audit delay in Croatia.

The reminder of the paper is structured as follows. The next section provides a brief literature review. The third section describes research design and variables used in the model. Research results are presented and discussed in Section four. Finally, the last section summarizes the main findings of research.

\section{Literature review}

Although the issue of timeliness is of great importance to standard setters, the theory in this area is not particularly developed [8, 9]. Still, there are numerous studies that have examined a variety of factors regarding audit delay. The majority of related studies were conducted in the USA and other Anglo-Saxon institutional settings $[1,5,6,8,9,15,16]$. However, in the recent years the issue has also become popular in other countries with different institutional and regulatory settings, like Malaysia [7], China [19], Greece [21], Spain [4], Turkey [23], etc. A great interest in researching this issue on international level additionally emphasizes its relevance.

Empirical results show that there exists a great variability among different countries with respect to the timelines of financial reporting and audit reporting lag. For example, the study of DeCeuster and Trappers [10] found that it takes Belgian companies longer to report their financial results than companies in Anglo-Saxon countries. Furthermore, prior research has established the importance of a number of variables in explaining audit reporting lag. These factors include, among others, industry and size of the company, profitability, gearing, extraordinary items, auditor business risk, audit complexity, audit firm characteristics and audit opinion.

While studies on audit delay share many similarities, they also present peculiarities that differentiate them [4]. This can be attributed to differences in observation periods, sample sizes and their compositions, measures of audit reporting lag and related variables, methodological approaches, institutional and regulatory settings. This also suggests that empirical research broadening the scope of the analysis and integrating many of these considerations may give us a more comprehensive picture of the effects of different factors on the timeliness of financial reporting and audit delay.

\begin{tabular}{|l|c|l|l|l|}
\hline \multicolumn{1}{|c|}{ Author } & Year & \multicolumn{1}{|c|}{ Sample } & Main methodology & \multicolumn{1}{c|}{ Main findings } \\
\hline \multicolumn{5}{|c|}{ Anglo-Saxon institutional setting } \\
\hline $\begin{array}{l}\text { Davies \& } \\
\text { Whittred [9] }\end{array}$ & 1980 & $\begin{array}{l}\text { Australia; 100 } \\
\text { public companies; } \\
\text { 1972-77 }\end{array}$ & $\begin{array}{l}\text { Rank correlation } \\
\text { Mann Whitney U test }\end{array}$ & $\begin{array}{l}\text { Size of company appears } \\
\text { to be a determinant of } \\
\text { the total reporting lag. }\end{array}$ \\
\hline
\end{tabular}




\begin{tabular}{|c|c|c|c|c|}
\hline Author & Year & Sample & Main methodology & Main findings \\
\hline $\begin{array}{l}\text { Ashton } \\
\text { et al. [1] }\end{array}$ & 1987 & $\begin{array}{l}\text { USA; } \\
488 \text { companies; } \\
1982\end{array}$ & OLS regression & $\begin{array}{l}\text { Audit delay is positively } \\
\text { related to total revenues } \\
\text { and operational com- } \\
\text { plexity. Audit delay } \\
\text { is negatively related to } \\
\text { public/non-public classi- } \\
\text { fication, overall quality } \\
\text { of internal control and } \\
\text { relative mix of audit } \\
\text { work. }\end{array}$ \\
\hline $\begin{array}{l}\text { Carslaw \& } \\
\text { Kaplan [6] }\end{array}$ & 1991 & $\begin{array}{l}\text { New Zealand; } \\
\text { public companies; } \\
1978 \text { and } 1988\end{array}$ & OLS regression & $\begin{array}{l}\text { The results indicate that } \\
\text { company size and sign of } \\
\text { income significantly af- } \\
\text { fect audit delay across } \\
\text { the two years examined. }\end{array}$ \\
\hline $\begin{array}{l}\text { Kinney \& } \\
\text { McDaniel } \\
{[15]}\end{array}$ & 1993 & $\begin{array}{l}\text { USA; } 85 \text { listed } \\
\text { companies; } \\
\text { 1986-1988 }\end{array}$ & OLS regression & $\begin{array}{l}\text { The results indicate } \\
\text { that firms with declin- } \\
\text { ing earnings reporting } \\
\text { corrections of interim } \\
\text { earnings that were } \\
\text { initially overstated also } \\
\text { tend to have signifi- } \\
\text { cantly increased audit } \\
\text { delay. }\end{array}$ \\
\hline $\begin{array}{l}\text { Kirshnan \& } \\
\text { Yang [16] }\end{array}$ & 2009 & $\begin{array}{l}\text { USA; listed } \\
\text { companies ( } 1,393 \\
\text { for audit lag } \\
\text { analysis and } \\
1,077 \text { for earnings } \\
\text { announcement } \\
\text { analysis), } \\
2001-2006\end{array}$ & OLS regression & $\begin{array}{l}\text { Both lags increased sig- } \\
\text { nificantly in the two-year } \\
\text { period 2001-2002 prior } \\
\text { to the introduction of } \\
\text { the accelerated filing re- } \\
\text { quirements and in the } \\
\text { period } 2003-2006 \text { when } \\
\text { the new filing require- } \\
\text { ments were in effect. } \\
\text { The likelihood that com- } \\
\text { panies announced earn- } \\
\text { ings prior to the audit re- } \\
\text { port date increased con- } \\
\text { siderably over the period } \\
2001-2006 \text {, but particu- } \\
\text { larly during } 2004-2006 \\
\text { when Section } 404 \text { of the } \\
\text { SOX was in effect. }\end{array}$ \\
\hline $\begin{array}{l}\text { Clatworthy } \\
\& \text { Peel [8] }\end{array}$ & 2010 & $\begin{array}{l}\text { UK; } 1,032,615 \\
\text { private } \\
\text { companies; } 2008\end{array}$ & $\begin{array}{l}\text { OLS regression with } \\
\text { White standard } \\
\text { errors and negative } \\
\text { binomial regression }\end{array}$ & $\begin{array}{l}\text { The presence of a pro- } \\
\text { fessionally qualified ac- } \\
\text { countant on the board, } \\
\text { the proportion of women } \\
\text { on the board, the size } \\
\text { of the board and the } \\
\text { presence and quality of } \\
\text { an auditor enhance the } \\
\text { timeliness of financial re- } \\
\text { porting. }\end{array}$ \\
\hline
\end{tabular}




\begin{tabular}{|c|c|c|c|c|}
\hline Author & Year & Sample & Main methodology & Main findings \\
\hline $\begin{array}{l}\text { Bronson } \\
\text { et al. [5] }\end{array}$ & 2011 & $\begin{array}{l}\text { USA; } 16.973 \\
\text { firm-year } \\
\text { observations; } \\
2000-2005\end{array}$ & $\begin{array}{l}\text { Pooled probit } \\
\text { regression with } \\
\text { heteroskedasticity- } \\
\text { robust standard } \\
\text { errors }\end{array}$ & $\begin{array}{l}\text { Results indicate revi- } \\
\text { sions to preliminary an- } \\
\text { nouncement when filing } \\
\text { the } 10-\mathrm{K} \text { report would } \\
\text { have been } 35 \% \text { lower } \\
\text { during } 2005 \text { if histor- } \\
\text { ical frequency of issu- } \\
\text { ing earnings releases af- } \\
\text { ter the audit report date } \\
\text { had not changed. }\end{array}$ \\
\hline \multicolumn{5}{|c|}{ Other institutional settings } \\
\hline $\begin{array}{l}\text { Owusu- } \\
\text { Ansah \& } \\
\text { Leventis [21] }\end{array}$ & 2006 & $\begin{array}{l}\text { Greece; } 95 \\
\text { listed } \\
\text { companies; } \\
1999\end{array}$ & OLS regression & $\begin{array}{l}\text { Multivariate regression } \\
\text { analysis suggests that } \\
\text { large companies, service } \\
\text { companies and compa- } \\
\text { nies audited by the for- } \\
\text { mer Big-5 audit firms } \\
\text { have shorter final report- } \\
\text { ing lead-time. Com- } \\
\text { panies in the construc- } \\
\text { tion sector, companies } \\
\text { whose audit reports were } \\
\text { qualified and companies } \\
\text { that had a greater pro- } \\
\text { portion of their equity } \\
\text { shares directly and in- } \\
\text { directly held by insid- } \\
\text { ers do not promptly re- } \\
\text { lease their audited finan- } \\
\text { cial statements. }\end{array}$ \\
\hline $\begin{array}{l}\text { McGee \& } \\
\text { Yuan [19] }\end{array}$ & 2008 & $\begin{array}{l}\text { China; } 18 \\
\text { Chinese } \\
\text { companies and } \\
21 \text { non- } \\
\text { Chinese } \\
\text { companies; } \\
2002-2006\end{array}$ & $\begin{array}{l}\text { Comparative analysis } \\
\text { T-test }\end{array}$ & $\begin{array}{l}\text { The audit opinion for the } \\
\text { average Chinese com- } \\
\text { pany was dated } 92.1 \\
\text { days after year-end. The } \\
\text { average date for non- } \\
\text { Chinese companies was } \\
65.5 \text { days. The means } \\
\text { for the two groups was } \\
\text { significantly different at } \\
\text { the } 1 \text { percent level. }\end{array}$ \\
\hline $\begin{array}{l}\text { Che-Ahmad } \\
\text { \& Abidin } \\
{[7]}\end{array}$ & 2008 & $\begin{array}{l}\text { Malaysia; } 343 \\
\text { listed } \\
\text { companies; } \\
1993\end{array}$ & OLS regression & $\begin{array}{l}\text { The findings indicated } \\
\text { that the mean audit de- } \\
\text { lay of Malaysian com- } \\
\text { panies is much longer } \\
\text { than the delay in West- } \\
\text { ern countries. The mul- } \\
\text { tivariate analysis showed } \\
\text { that director sharehold- } \\
\text { ings, total assets, num- } \\
\text { ber of subsidiaries, type } \\
\text { of audit firms, audit } \\
\text { opinion and return on } \\
\text { equity are important de- } \\
\text { terminants of audit de- } \\
\text { lay. }\end{array}$ \\
\hline
\end{tabular}




\begin{tabular}{|c|c|c|c|c|}
\hline Author & Year & Sample & Main methodology & Main findings \\
\hline $\begin{array}{l}\text { Bonsón- } \\
\text { Ponte et al. } \\
{[4]}\end{array}$ & 2008 & $\begin{array}{l}\text { Spain; } 105 \\
\text { companies ( } 403 \\
\text { company-year } \\
\text { observations); } \\
2002-2005\end{array}$ & $\begin{array}{l}\text { Pooled OLS } \\
\text { regression }\end{array}$ & $\begin{array}{l}\text { The regulatory pressures } \\
\text { and the company size } \\
\text { relative to its sector } \\
\text { are influencing factors } \\
\text { when the audit report is } \\
\text { signed. The companies } \\
\text { of larger relative size sign } \\
\text { the audit report in fewer } \\
\text { days (negative sign). }\end{array}$ \\
\hline Türel [23] & 2010 & $\begin{array}{l}\text { Turkey; } 211 \\
\text { listed } \\
\text { companies; } \\
2007\end{array}$ & OLS regression & $\begin{array}{l}\text { The multivariate regres- } \\
\text { sion analysis indicates } \\
\text { that both sign of income, } \\
\text { audit opinion, auditor } \\
\text { firm and industry affect } \\
\text { timeliness. The findings } \\
\text { indicate that the compa- } \\
\text { nies, which report net in- } \\
\text { come, have standard au- } \\
\text { dit opinion, and oper- } \\
\text { ate in manufacturing in- } \\
\text { dustry release their fi- } \\
\text { nancial statements ear- } \\
\text { lier while the companies } \\
\text { that are audited by the } \\
\text { big four audit firms re- } \\
\text { port their financial state- } \\
\text { ments later. }\end{array}$ \\
\hline
\end{tabular}

Table 1: Analysis of previous studies

\section{Research design}

Consistent with prior literature [3,17], audit delay or audit reporting lag is measured as a function of the number of days that elapse from the closure of the accounting period until the date of the audit report. In order to investigate the association between audit reporting lag and selected independent variables, the following model is developed:

$$
\begin{aligned}
A D_{i t}= & \alpha_{0}+\beta_{1} \text { Big }_{i} t+\beta_{2} \text { ModOp }_{i t}+\beta_{3} R O A_{i t}+\beta_{4} \text { Lev }_{i t}+\beta_{5} \text { InvRec }_{i t} \\
& +\beta_{6} T A_{i t}+\beta_{7} \ln \text { Size }_{i t}+\beta_{8} A C_{i t}+u_{i t}
\end{aligned}
$$

Independent variables included in the model are described in Table 2.

The first two variables are auditor related variables. Audit firm type (Big4) is a dichotomous variable introduced to explain potential differences in audit firm size on audit delay. Namely, the Big Four auditors are larger and therefore may be able to perform audit faster due to greater personnel capacity, superior audit technology, experience in auditing public companies and economies of scale [2, 4, 21]. Audit opinion $(\operatorname{Mod} O p)$ is also a dichotomous variable with the value of one if the audit opinion is a modified, and zero otherwise. Companies with modified opinions are expected to encounter audit delays since a modified audit report conveys negative 


\begin{tabular}{|l|l|l|}
\hline \multicolumn{1}{|c|}{ Variable } & \multicolumn{1}{|c|}{ Symbol } & \multicolumn{1}{c|}{ Description / Measurement } \\
\hline Audit firm type & Big4 & 1 if a Big 4 audits firm; and 0 otherwise \\
\hline Audit opinion & ModOp & $\begin{array}{l}\text { 1 if audit opinion is modified; and 0 } \\
\text { otherwise }\end{array}$ \\
\hline Profitability & Lev & Net income / Total assets \\
\hline Leverage & InvRec & Total liabilities / Total assets \\
\hline Audit effort & Inventories + Receivables) / Total assets \\
\hline $\begin{array}{l}\text { Absolute level of } \\
\text { total accruals }\end{array}$ & $\ln$ Size & $\begin{array}{l}\mid \text { Net income - Operating Cash Flow) } \\
\text { Total assets } \mid\end{array}$ \\
\hline Company size & company \\
\hline Audit committee & $\begin{array}{l}1 \text { if audit committee exists in a company; } \\
\text { and 0 otherwise }\end{array}$ \\
\hline
\end{tabular}

Table 2: Independent variables description

information and auditors may spend additional time on audit procedures in order to reduce any uncertainties or disagreements $[2,4,21]$.

Davies and Whittred [9] offer several arguments for this kind of reasoning: i) professional auditing standards require that auditors undertake all possible and reasonable steps to issue an unqualified opinion before they can issue a qualified opinion; ii) auditors do not like to issue qualified opinions to their clients, so it is expected that they will broaden their procedures to resolve any uncertainties; iii) management of a company does not want to receive a qualified audit report, so they are likely to start negotiations with their auditors. All these actions will lead to an increase in the reporting lag.

Variables Profitability (ROA), Leverage (Lev), Audit effort (InvRec) and Absolute level of total accruals $(T A)$ are included in the model to proxy for client complexity and/or engagement risk. Bamber et al. [3] argue that the amount of audit work to be done is an increasing function of the auditor's business risk associated with the client. Business risk will increase if client's financial position deteriorates. Both profitability and leverage can be used as indicators of client's financial condition. Less profitable companies and companies with a greater amount of debt tend to be associated with financial distress and hence a greater risk of bankruptcy [6]. On the other hand, profitable companies may require auditors to complete audit of their accounts earlier in order to convey the 'good news' [1,6]. Variable InvRec measures audit effort/risk or hand-to-audit asset involving audit time and effort beyond that of other assets. Variable $T A$ is also used as an indicator of audit inherent risk as accruals have a higher risk of error and require more audit effort. Namely, Francis and Krishnan [11] argue audits of high-accrual companies pose more uncertainty than audits of low-accrual companies because of the potential of estimation error and a greater chance that high-accrual companies have undetected asset realization and/or going concern problems related to a higher level of accruals. Since higher levels of accounting accruals increase the risk of information reliability (because they are inherently subjective, linked to future realizations and prone to opportunistic earnings management), a positive relationship between audit delay and the absolute 
level of total accruals is expected.

Company Size (Size) is a variable commonly used to explain variability in audit delay. Although larger companies have more extensive and complex accounts and may therefore require more time for auditing, empirical research generally supports a negative relationship between audit delay and company size $[1,3,6,14,15]$. These findings can be explained with several arguments. Firstly, large companies face greater external pressure to release the financial statement promptly [3] and they can also exert more pressure and demand more timely completion of their audits [3, $6,14]$. Moreover, they are likely to have better internal controls, allowing auditors to perform more interim compliance and substantive tests, thereby reducing year-end audit work [20].

Finally, variable Audit Committee $(A C)$ is used to capture the effect of the corporate governance mechanism on audit reporting lag. The committee oversees financial reporting procedures, the internal control system, risk management practice and the internal and external audit process. Since 2005 when the Audit Act became effective, all entities of public interest in Croatia are obliged to set up an audit committee. Although setting up an audit committee is a legal obligation, many companies of public interest in Croatia still haven not established it. Therefore, $A C$ is a dichotomous variable with the value one if a company has established an audit committee, and zero otherwise. We expect a negative relation between companies having audit committees established and audit delay.

\section{Empirical findings}

\subsection{Sample description}

\begin{tabular}{|c|c|c|c|c|c|c|}
\hline \multicolumn{1}{|c|}{ Panel A: Continuous variables $(n=281)$} \\
\hline Variable & $A D$ & ROA & Lev & InvRec & TA & $\ln$ Size \\
\hline Mean & 105.90 & 0.0016 & 0.4789 & 0.2221 & 0.0625 & 20.1423 \\
\hline Median & 110 & 0.0044 & 0.4409 & 0.1913 & 0.0352 & 19.9926 \\
\hline Std. dev. & 29.95 & 0.1011 & 0.2802 & 0.1963 & 0.1237 & 1.2019 \\
\hline \multicolumn{7}{|c|}{ Panel B: Categorical variables $(n=281)$} \\
\hline Frequency of 1 & Big4 & ModOp & AC \\
\hline Percentage of 1 & 76 & 38 & 133 \\
\hline
\end{tabular}

Table 3: Descriptive statistics of variables

The research is conducted on a sample of non-financial companies listed on the Zagreb Stock Exchange (ZSE), covering the period from 2008 to 2011. This period is chosen since the year 2008 was the first year of organized collection of audit reports in a publicly available database - Register of Financial Statements created by the Financial Agency (FINA). The Register is also used to collect data from financial statements, while data regarding existence or non-existence of an audit committee are collected from the ZSE Annual Questionnaire - Code of Corporate Governance. 
Finally, depending on data availability ${ }^{\ddagger}$, the final sample included 281 company-year observations. Descriptive statistics of analyzed variables is presented in Table 3 .

As can be noticed from Table 3, mean audit delay is 106 days. Namely, audited information becomes available after a period that ranges from 4 days for the company with the shortest audit delay, up to 208 days for the company with the longest audit delay. Prior studies indicate that the release of annual financial statements is delayed by the audit function by an average of over 50 days across different countries [18].

\subsection{Multivariate analysis}

Our model is estimated by pooled OLS regression analysis. With panel data, usual OLS standard errors are incorrect unless there is no cluster effect and so robust standard errors that allow "cluster correlation" (and heteroskedasticity) should be used [24]. Standard errors clustered by a company are unbiased and produce correctly sized confidence intervals regardless of the firm effect being permanent or temporary [22]. Consequently, we use White standard errors which are robust to within cluster correlation (i.e. Rogers or clustered standard errors). Also, since many panel data sets have more firms than years, a common approach is to include dummy variables for each time period (to absorb the time effect). If the time effect is fixed the time dummies completely remove the correlation between observations in the same time period [22]. Therefore, we use year dummies to account for time-fixed effects (F-test for joint significance is 2.79 with p-value 0.0437). Also, calculated multicollinearity tests suggest that collinearity is not a serious issue (i.e. variance inflation factors are lower than 5 ).

As Table 4 shows, the F-statistic of the model is significantly different from zero, indicating that a subset of the explanatory variables does explain the variation in audit delay. The value of $\mathrm{R}^{2}$ indicates that only about $17 \%$ of the variation in audit delay is explained by the model. The low $\mathrm{R}^{2}$ value can be compared with similar studies. For example, Ashton et al. [1] adjusted $\mathrm{R}^{2}$ for the overall sample and it was $26.5 \%$; values of Clatworthy and Peel $[8] \mathrm{R}^{2}$ were $13.29 \%$ and $15.03 \%$; Owusu-Ansah and Leventis' [21] $\mathrm{R}^{2}$ values were $36.8 \%$ and $44.2 \%$; Bonsón-Ponte et al. [4] $\mathrm{R}^{2}$ value is $20.03 \%$ and Türel [23] $\mathrm{R}^{2}$ was $13.3 \%$. The low $\mathrm{R}^{2}$ is common in social sciences, especially for cross-sectional analysis [24]. In such studies, the signs, magnitudes, and significance of the estimated parameters are of primary interest. Regression analysis results are presented in Table $4 .{ }^{\S}$

The results show that only three variables are statistically significant in explaining audit delay in Croatia. Namely, audit delay is inversely related to profitability $(\mathrm{p}<0.05)$ and directly related to financial leverage $(\mathrm{p}<0.01)$, which is consistent with the findings described previously $[3,6]$. Moreover, our results provide evidence that the existence of an audit committee is negatively related to audit delay ( $p<$ 0.01). This finding emphasizes the importance of a corporate governance mechanism in promoting the timeliness of financial reporting.

In order to test robustness of our results we estimated the model separately for each year. The results of a separate estimation demonstrate the following: 1) the

\footnotetext{
¥ The greatest loss of observations was due to non-existence of data regarding an audit committee.

$\S$ Year dummies are included but not reported for sake of brevity.
} 
financial leverage has expected sign and is statistically significant on conventional levels in all years except the year 2009; 2) a variable audit committee is not statistically significant only in the last year, while the expected sign remains as expected in all years; and 3) profitability is inversely related to audit delay in all years; however, it is only statistically significant in 2009 and 2010. Moreover, when estimating the model separately for each year, two more variables are found to be statistically significant: modified audit opinion in the year 2009 and size in 2010 and 2011. We also estimated the model using logarithmic transformation of audit delay $[1,14,16]$. However, the results remain similar, but the model has lower explanatory power.

\begin{tabular}{|c|c|c|c|c|c|}
\hline Independent variable & Expected sign & Coeff. & t-statistics & p-value & VIF \\
\hline INTERCEPT & $?$ & $171.4131^{a}$ & 4.29 & 0.000 & \\
\hline Big 4 & - & 6.6771 & 1.08 & 0.283 & 1.30 \\
\hline$M o d O p$ & + & -9.2831 & -1.26 & 0.212 & 1.04 \\
\hline$R O A$ & - & $-50.2117^{b}$ & -2.17 & 0.032 & 1.88 \\
\hline$L e v$ & + & $24.9872^{a}$ & 3.24 & 0.002 & 1.25 \\
\hline InvRec & + & -11.7944 & -1.03 & 0.304 & 1.12 \\
\hline$T A$ & + & 7.3810 & 0.44 & 0.658 & 1.67 \\
\hline $\ln$ Size & - & -3.1450 & -1.54 & 0.126 & 1.48 \\
\hline$A C$ & - & $-12.3950^{a}$ & -2.78 & 0.006 & 1.09 \\
\hline \multicolumn{2}{|c|}{ Observations } & 281 & \multirow{4}{*}{\multicolumn{3}{|c|}{$\begin{array}{l}a, b \text { means significant at } \\
1 \% \text { and } 5 \% \text { level (two-sided } \\
\text { tests), respectively }\end{array}$}} \\
\hline \multicolumn{2}{|c|}{$\mathrm{R}$ - square } & 0.1746 & & & \\
\hline \multicolumn{2}{|c|}{ F-test } & 5.94 & & & \\
\hline \multicolumn{2}{|c|}{ Prob $>F$} & 0.0000 & & & \\
\hline
\end{tabular}

Table 4: Estimated results by pooled OLS regression

\section{Conclusion}

Timeliness is an important and useful characteristic of accounting information. Thereby, it is of great interest to different regulatory bodies and standard setters. However the timeliness of financial reporting is directly affected by the length of auditing. Our data indicate that the average audit delay in Croatia is 106 days which is below legal requirements set by the Capital Market Act; however, it is much longer than average audit delay in developed countries. The aim of this study was to analyse the effect of several company and audit related variables on audit delay in Croatia. Our findings indicate that lower profitability and higher indebtedness increase audit reporting lag, while the existence of an audit committee contributes to timely financial reporting by shortening audit delay. The results of this paper could be of interest not only to academics but also to standard setters and regulators in the process of improvement of the quality of financial reporting. However, potential limitations of our study are related to a small sample size, sample selection bias and the problem of omitted variables (namely variables that explain different corporate governance aspects, institutional setting, audit firm and audit technology characteristics). These limitations can also be used as suggestions for future research. 


\section{References}

[1] Ashton, R. H., Willingham, J. J. and Elliott, R. K. (1987). An empirical analysis of audit delay. Journal of Accounting Research, Vol. 25, No. 2, 275-292.

[2] Ashton, R. H., Graul, P. R. and Newton, J. D. (1989). Audit delay and the timeliness of corporate reporting. Contemporary Accounting Research, Vol. 5, No. 2, 657-673.

[3] Bamber, E. M., Bamber, L. S. and Schoderbek, M. P. (1993). Audit structure and other determinants of audit report lag: An empirical analysis. Auditing: A Journal of Practice \& Theory, Vol. 12, No. 1, 1-23.

[4] Bonsón-Ponte, E., Escobar-Rodríguez, T. and Borrero-Domínguez, C. (2008). Empirical Analysis of Delays in the Signing of Audit Reports in Spain. International Journal of Auditing, Vol. 12, 129-140.

[5] Bronson, S. N., Hogan, C. E., Johnson, M. F. and Ramesh, K. (2011). The unintended consequences of PCAOB auditing Standard Nos. 2 and 3 on the reliability of preliminary earnings releases. Journal of Accounting and Economics, Vol. 51, No. 1, 95-114.

[6] Carslaw, C. and Kaplan, S. E. (1991). An examination of audit delay: Further evidence from New Zealand. Accounting and Business Research, Vol. 22, No. 85, 21-32.

[7] Che-Ahmad, A. and Abidin, S. (2008). Audit delay of listed companies: A case of Malaysia. International Business Research, Vol. 1, No. 4, 32-42.

[8] Clatworthy, M. A. and Peel, M. J. (2010). Does Corporate Governance Influence the Timeliness of Financial Reporting? Evidence from UK Private Companies. http://www .hec.edu/Faculty-Research/Research-Seminars/(offset)/ 30/(dept) /133 [Accessed on 8 July 2013].

[9] Davies, B. and Whittred, G. P. (1980). The Association Between Selected Corporate: Attributes and Timeliness in Corporate: Reporting: Further Analysis. Abacus, Vol. 16, No. 1, 48-60.

[10] DeCeuster, M. and Trappers, D. (1993). Determinants of the Timeliness of Belgian Financial Statements. Working Paper, University of Antwerp.

[11] Francis, J. R. and Krishnan, J. (1999). Accounting accruals and auditor reporting conservatism. Contemporary Accounting Research, Vol. 16, No. 1, 135-165.

[12] Givoly, D. and Palmon, D. (1982). Timeliness of annual earnings announcements: Some empirical evidence. Accounting Review, 486-508.

[13] IASB (2008), Exposure Draft of An Improved Conceptual Framework for Financial Reporting: Chapter 1: The Objectives of Financial Reporting, Chapter 2: Qualitative Characteristics and Constraints of Decision-useful Financial Reporting Information. http://www.ifrs.org/Current-Projects/IASB-Projects/ConceptualFramework/ EDMay08/Documents/conceptual_framework_exposure_draft.pdf [Accessed 05/07/2013].

[14] James, D. N. and Ashton, R. H. (1989). The association between audit report technology and audit delay. Auditing: A Journal of Practice \& Theory, Vol. 8, No. 1, $22-37$.

[15] Kinney, W. R. and McDaniel, L. S. (1993). Audit delay for firms correcting quarterly earnings. Auditing: A Journal of Practice and Theory, Vol. 12, No. 2, 135-142.

[16] Kirshnan, J. and Yang, J. S. (2009). Recent trends in audit report and earnings announcement lags. Accounting Horizons, Vol. 23, No. 3, 265-288.

[17] Knechel, W. R. and Payne, L. F. (2001). Additional evidence on audit report lag. Auditing: A Journal of Practice \& Theory, Vol. 20, No.1, 137-146.

[18] Lai, K. W., Hom, H. and Cheuk, L. M. (2005). Audit Reporting Lag, Audit Partner Rotation and Audit Firm Rotation: Evidence from Australia. 
http://ssrn.com/abstract=783684 [Accessed on 8 July 2013].

[19] McGee, R. W. and Yuan, X. (2008). Corporate Governance and the Timeliness of Financial Reporting: An Empirical Study of the People's Republic of China. http://ssrn. com/abstract=1131338 [Accessed 8 July 2013].

[20] Ng, P. P and Tai, B. Y. (1994). An empirical examination of the determinants of audit delay in Hong Kong. The British Accounting Review, Vol. 26, No. 1, 43-59.

[21] Owusu-Ansah, S. and Leventis, S. (2006). Timeliness of Corporate Annual Financial Reporting in Greece: A Research Note. European Accounting Review, Vol. 15, No. 2, 273-287.

[22] Petersen, M. A. (2009). Estimating Standard Errors in Finance Panel Data Sets: Comparing Approaches. Review of Financial Studies, Vol. 22, No. 1, 435-480.

[23] Türel, A. (2010). Timeliness of financial reporting in emerging capital markets: Evidence from Turkey. Istanbul University Journal of the School of Business Administration, Vol. 39, No. 2, 227-240.

[24] Wooldridge, J. (2012). Introductory Econometrics: A Modern Approach, Cengage Learning.

[25] Zakon o tržištu kapitala, Narodne novine 88/08, 146/08, 74/09, 54/13, 159/13 [Croatian Capital Market Act, Official Gazette, 88/08, 146/08, 74/09, 54/13, 159/13]. http://www . hanfa.hr/getfile/40373/ZTK_nesluzbeni_procisceni_tekst_2014.pdf [Accessed on 8 July 2013]. 